\title{
Website Perpustakaan “Library HUB” Dengan Pencarian Buku Berdasarkan Gambar Menggunakan Google MLKit
}

\author{
Malvin Patrick Kurniawan, S.Kom. ${ }^{1}$, Indra Maryati, S.Kom., M.Kom. ${ }^{2}$ \\ ${ }^{1}$ Program Studi Informatika, Institut Sains dan Teknologi Terpadu Surabaya, Surabaya \\ ${ }^{2}$ Program Studi Sistem Informasi, Universitas Ciputra, Surabaya \\ e-mail: *11malvinpatrickk@gmail.com, ${ }^{2}$ indra.maryati@ ciputra.ac.id
}

\begin{abstract}
Abstrak
Mahasiswa dalam proses belajar memerlukan sarana perpustakaan sebagai sumber pengetahuan. Zaman sekarang perpustakaan dapat diakses melalui website bahkan aplikasi mobile sehingga memudahkan mahasiswa dalam mencari dan meminjam buku. Beberapa Universitas seperti Universitas Ciputra Surabaya dan ISTTS menggunakannya untuk memberikan informasi mengenai katalog buku yang terdapat pada perpustakaan seperti melihat ketersediaan buku, dan status buku. Dalam mencari informasi buku, mahasiswa dapat mengunjungi perpustakaan secara langsung dengan dukungan kartu kepesertaan SUPER atau SAKTI maupun mengunjungi website perpustakaan universitas yang dibutuhkan. Namun dengan cara demikian mahasiswa harus mengunjungi setiap website universitas untuk mencari buku yang dibutuhkan. Untuk mengatasi masalah diatas, penelitian ini akan membangun sistem pihak ketika yang akan menghubungkan sistem perpustakaan online dan mahasiswa atau pengguna. Dengan sistem ini, mahasiswa tidak perlu mengunjungi website setiap perpustakaan untuk mencari buku yang sama. Sistem ini menampilkan semua daftar buku yang berkaitan dari seluruh perpustakaan dalam sekali pencarian. Selain itu untuk memudahkan pembayaran, sistem akan terintegrasi dengan sistem wallet digital. Sehingga dengan sistem ini mahasiswa semakin mudah untuk mendapatkan informasi dan melakukan peminjaman buku.
\end{abstract}

Kata kunci-Perpustakaan, Deteksi Teks, Pengenalan Teks, MLKit, Pencarian Gambar

\begin{abstract}
Students need a library as a source of their knowledge and learning process. Nowadays, libraries can be accessed by a website and mobile application. It makes easier for students to search and borrow a book. Several universities, such as Universitas Ciputra Surabaya and ISTTS use it to provide information about their book catalog and status of the books in their library. In searching for the book's information, students can visit the library directly with SUPER and SAKTI membership or visit the intended universities library websites. However, it is less efficient when they must visit each university library website to find their needed books. To overcome these problems, a third-party system that connects the online library systems with the students or users was developed. With this system, students do not have to visit each of the library's website to find the books. It shows the display of all related books needed from the library system in one time searching. In order to make the payment easier, the system will be integrated with a digital wallet system. In an inconclusion, it helps students easier to find books and borrow books.
\end{abstract}

Keywords—Library, Text Detection, Text Recognition, MLKit, Image Searching 


\section{PENDAHULUAN}

$\mathrm{B}$ Berawal dari keterbatasan buku pendukung pengajaran di perpustakaan PT, dimana peneliti tidak menemukan buku yang dicari. Dan kemudian pustakawan mengarahkan untuk dapat mencari di perpustakaan PT lainnya dengan menggunakan kartu SUPER. Kartu SUPER adalah kartu yang digunakan untuk mengakses layanan seluruh perpustakaan yang tergabung dalam Forum Perpustakaan Perguruan Tinggi Indonesia (FPPTI) Jawa Timur [1]. Selain kartu SUPER ada juga kartu SAKTI, yang memiliki fungsi yang sama dengan kartu SUPER. Kartu SAKTI adalah sebuah kartu yang dapat digunakan dosen dan mahasiswa sebagai akses untuk memanfaatkan layanan dan koleksi perpustakaan-perpustakaan Perguruan Tinggi Negeri yang tergabung dalam Forum Kegiatan Perpustakaan Perguruan Tinggi Negeri (FKP2TN).

Dengan tersedianya 2 kartu tersebut sangat mendukung program resource sharing yang dibentuk oleh forum perpustakaan, sehingga dapat meningkatkan minat baca masyarakat. Resource sharing adalah berbagi sumber daya perpustakaan dengan perpustakaan peserta tertentu di antara mereka sendiri berdasarkan prinsip kerja sama. Hal ini berlaku untuk berbagi dokumen, tenaga kerja, layanan, ruang dan peralatan. Kegiatan berbagi sumber daya dimotivasi oleh beberapa faktor, seperti mulai dari memperluas jaringan dan memenuhi komponen penilaian akreditasi perpustakaan yang dilakukan oleh Perpustakaan Nasional [2].

Jika dilihat dari sisi pengembangan teknologi informasi dan komunikasi (TIK), masingmasing perpustakaan memiliki sistem yang dikembangkan secara terpisah, tanpa ada koordinasi antara satu perpustakaan dengan perpustakaan lainnya, dan menyesuaikan dengan kondisi perpustakaan tersebut [3][4]. Namun dengan cara demikian, mahasiswa harus mengunjungi masing-masing website untuk mencari buku yang dibutuhkan.

Untuk mengatasi masalah tersebut, penelitian ini akan membangun sistem pihak ketiga yang akan menghubungkan perpustakaan secara online dengan mahasiswa. Dengan demikian, mahasiswa tidak lagi perlu mengunjungi website perpustakaan setiap universitas, karena sistem ini dapat menampilkan semua daftar buku yang berkaitan dalam sekali pencarian. Selain itu untuk memudahkan transaksi pembayaran, sistem akan didukung dengan sistem wallet digital. Pada sistem ini juga terdapat pencarian buku berdasarkan gambar sehingga mempercepat proses pencarian buku. Serta sistem ini dapat memberikan fasilitas kepada partner perpustakaan untuk lebih bermanfaat dan berkontribusi dalam menyediakan buku bagi mahasiswa.

\section{METODE PENELITIAN}

Penelitian ini dilakukan dengan melalui beberapa tahapan. Tahap pertama adalah peneliti melakukan analisis terhadap sistem perpustakaan yang berjalan selama ini, analisis permasalahan sampai dengan analisis kebutuhan. Tahap kedua adalah peneliti mencoba menjabarkan beberapa teknologi yang digunakan dalam penelitian. Tahap ketiga adalah melakukan desain dari sistem yang diusulkan. Kemudian untuk hasil dan pembahasan, kesimpulan, dan saran dibahas pada subbab yang berbeda.

\subsection{Tahapan Analisis}

Sebelum merancang sebuah sistem, perlu dilakukan analisis terlebih dahulu untuk mengetahui cara kerja, permasalahan sistem, bahkan dapat mengetahui kebutuhan sistem yang akan dirancang. 


\subsubsection{Permasalahan pada Sistem Perpustakaan Saat Ini}

Aplikasi perpustakaan, baik desktop, website, dan mobile, pada saat ini hanya tersedia bagi perpustakaan internal saja. Ketika member melakukan pencarian buku, user harus memasukkan kata kunci berupa judul buku secara manual. Pada aplikasi yang telah ada registrasi member hanya dapat dilakukan dengan menggunakan email, tidak menyediakan login dengan menggunakan Google akun atau sejenisnya. Dalam transaksi peminjaman, pembayaran biaya peminjaman buku dilakukan secara manual. Demikian juga pada saat member membayar sanksi denda ketika terlambat mengembalikan buku pinjaman.

Akibat dari kekurangan tersebut menimbulkan masalah pada pemakaian aplikasi yang ada. Berikut beberapa permasalahan yang timbul:

- Aplikasi perpustakaan hanya digunakan untuk kebutuhan internal, sehingga user harus membuka situs masing-masing perpustakaan untuk melakukan pencarian buku yang sama. Hal ini tidak efisien apabila buku yang dicari tidak ditemukan, lalu user mencari buku pada situs yang lain. Selain itu perpustakaan yang belum terkenal akan kurang dikunjungi oleh pencari buku.

- Pada aplikasi perpustakaan tidak menyediakan pencarian buku secara otomatis. Hal ini menyebabkan user harus mengetikkan secara manual judul buku yang ingin dicari.

- Pada aplikasi perpustakaan member harus memasukkan data diri seperti email, nama, nomor telepon. Hal ini membuat member yang ingin menggunakan website tersebut harus memasukkan data secara manual dan melakukan verifikasi email terlebih dahulu. Tentu hal ini kurang efisien pada zaman sekarang dimana Google maupun sosial media menyediakan autentikasi menggunakan akun Google atau sosial media yang ada.

- Pada sistem perpustakaan yang ada tidak memiliki sistem wallet, sehingga untuk pembayaran sanksi denda member dilakukan secara manual. Hal ini juga menyebabkan kerugian bagi perpustakaan, karena perpustakaan hanya akan mendapatkan biaya ganti rugi ketika member datang ke perpustakaan.

\section{1.2 Analisis Kebutuhan Sistem Perpustakaan}

Penelitan ini mengembangkan sistem perpustakaan yang menjadi penghubung antara beberapa perpustakaan dan member, sehingga dibutuhkan mekanisme pendataan perpustakaan, peminjaman, dan sanksi yang sedikit berbeda dari sistem perpustakaan saat ini. Berikut akan dijelaskan fitur-fitur yang mendukung sistem perpustakaan pada penelitian ini:

- Sistem akan menampung beberapa perpustakaan yang dapat memasukkan data buku yang dimiliki sehingga buku-buku yang telah dimasukkan dapat dicari oleh member. Karena sistem akan digunakan oleh banyak perpustakaan, maka diperlukan pencatatan biaya peminjaman, sanksi keterlambatan.

- Fitur login menggunakan akun Google dan login secara manual. Login dengan menggunakan akun Google memberikan kemudahan bagi member sehingga hanya perlu memilih akun yang akan digunakan untuk login. Namun terdapat login secara manual sebagai antisipasi apabila member tidak menggunakan akun Google.

- Fitur pencarian buku secara otomatis menggunakan gambar. Dengan fitur ini member cukup memfoto cover buku, maka aplikasi akan menampilkan daftar buku serupa.

- Sistem wallet yang memudahkan transaksi antara member dan perpustakaan. Wallet dapat di topup menggunakan payment gateway. Selain menggunakan payment gateway, member dapat request topup pada perpustakaan. Saldo pada wallet dapat dicairkan dengan cara request pencairan dana pada admin.

- Member dapat melakukan pemesanan (booking) buku, namun stok buku tidak berkurang. Pemesanan buku digunakan sebagai penanda bagi perpustakaan bahwa buku tersebut akan dipinjam oleh member. Apabila member lain memesan buku yang sama, maka yang akan 
mendapatkan buku tersebut adalah member yang mengambil buku lebih dahulu pada perpustakaan. Stok akan berkurang setelah member berhasil melakukan peminjaman dengan syarat mempunyai saldo sebesar 50.000 rupiah sebagai deposit jaminan setiap buku.

- Sistem sanksi denda harian dimana perpustakaan akan mendapat uang sanksi keterlambatan sebesar yang telah ditentukan sebelumnya. Setiap peminjaman memiliki batas sanksi maksimal 50.000. Apabila buku yang dipinjam mengalami kerusakan atau hilang, maka perpustakaan berhak memberikan sanksi denda tambahan tergantung harga setiap buku.

- Setiap akun perpustakaan memerlukan verifikasi dari admin untuk dapat beroperasi meminjamkan buku pada member.

- Setiap akun member memerlukan verifikasi dari admin untuk dapat melakukan pemesanan dan peminjaman buku mengingat member dapat registrasi secara bebas. Untuk mengurangi beban admin, terdapat fitur verifikasi member oleh perpustakaan.

\subsection{Teknologi yang Digunakan}

Agar objek penelitian ini dapat berjalan dengan baik, maka diperlukan beberapa teknologi yang akan digunakan untuk pengembangan objek penelitian ini, yaitu:

- Web Framework, utk pembuatan situs. Framework adalah sebuah software untuk memudahkan programmer membuat aplikasi atau web yang isinya adalah berbagai fungsi, plugin, dan konsep sehingga membentuk suatu sistem tertentu [5]. Framework yang akan digunakan adalah AngularJS dan CodeIgniter. Angular.js adalah salah satu framework MVC, berbasis Javascript, dan merupakan teknologi yang sangat populer dan memiliki keunggulan dalam dokumentasi yang terstruktur dan lengkap [6].

- Cloud Database, penggunaan teknologi ini dikhususkan agar data dapat diakses secara realtime dan mendukung fungsi web. Database yang digunakan adalah Firebase dan MySQL Server. Firebase adalah layanan Google yang berguna untuk membantu para developer untuk mengembangkan aplikasi [7].

- Web Service, digunakan untuk komunikasi antara web dengan cloud database, dan juga service pihak ke-3 yang membutuhkan, seperti MidTrans, Firebase Cloud Message, dan Google Authentication. Web services memungkinkan interoperabilitas lintas platform atau cross-platform [8].

- Machine Learning Library utk Android, dibutuhkan untuk melakukan implementasi ML ke dalam aplikasi Android. Library yang akan digunakan yaitu Google ML Kit [9]. Teknologi OCR adalah salah satu aplikasi pengenalan pola, cabang dari machine learning [10].

\section{3 Tahap Desain}

Sebagai hasil dari tahapan analisis, peneliti membuat sebuah desain arsitektur dari sistem perpustakaan yang akan dibangun. Arsitektur ini terdapat beberapa pihak ketiga (API) yang akan mendukung sistem yaitu: Firebase Cloud Messaging (FCM), Midtrans, Google Client dan Google MLKit. 


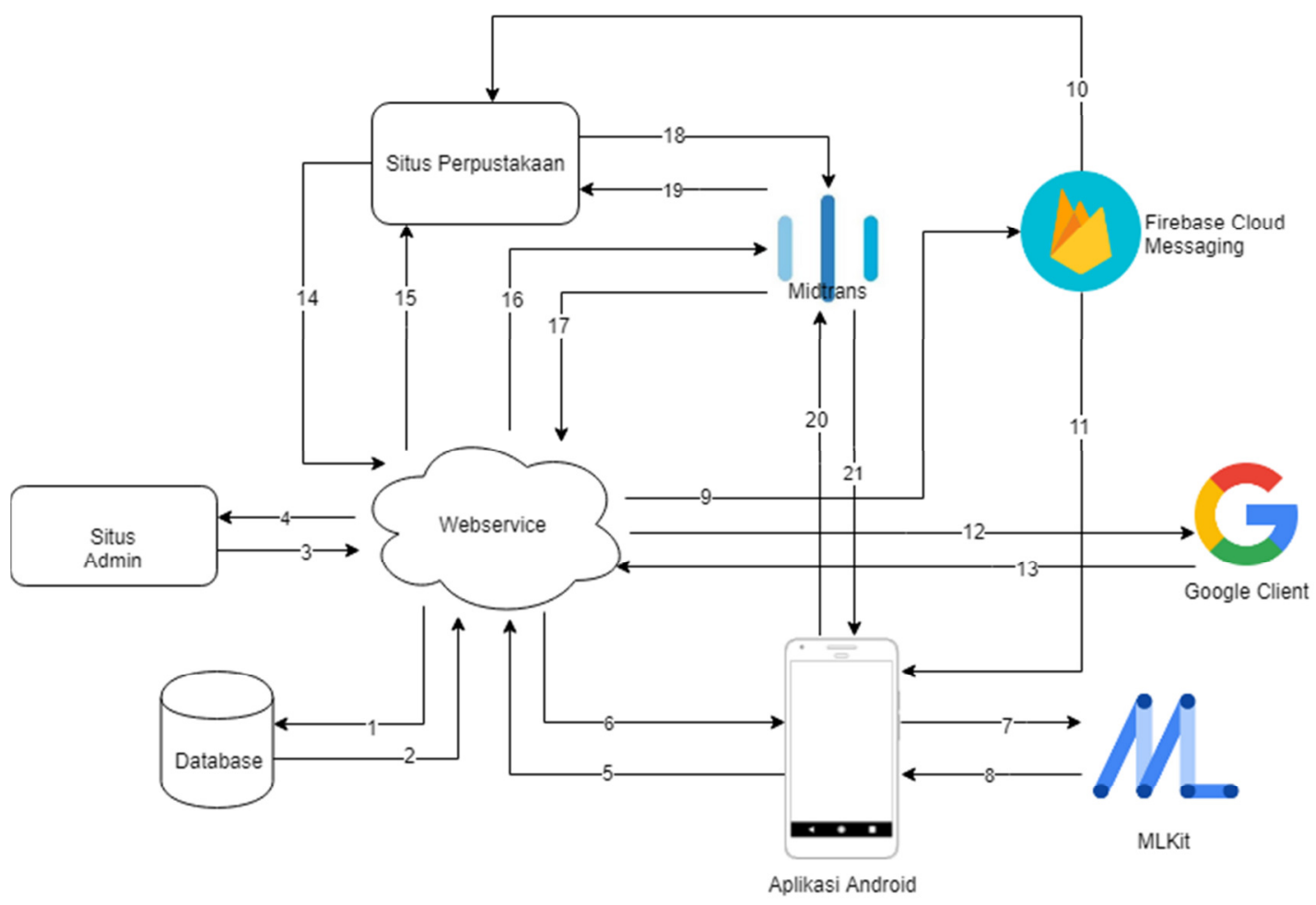

Gambar 2. Arsitektur Sistem

Penjelasan dari gambar 2 adalah sebagai berikut. Webservice akan mengakses database secara langsung untuk memasukkan dan mengubah data berdasarkan permintaan client. Database akan mengembalikan data berdasarkan query yang diberikan. Website admin dapat melakukan request pada webservice dalam proses login, melihat dan mengubah data yang ada pada sistem Library HUB. Webservice akan mengembalikan data sesuai dengan permintaan website admin. Aplikasi android dapat melakukan request ke webservice untuk login, register, menampilkan data dan keperluan lainnya. Pada tahap ini juga digunakan untuk meminta token transaksi Midtrans untuk user melakukan pembayaran. Webservice akan mengembalikan permintaan dari aplikasi Android. Aplikasi Android mengirim gambar pada Google MLKit untuk diproses sesuai permintaan, dalam penelitian ini aplikasi Android akan melakukan request deteksi OCR. Google MLKit akan mengembalikan data teks yang telah terdeteksi pada aplikasi Android. Webservice akan mengirimkan payload data berisi konten dari notifikasi yang diinginkan. Melalui request ke FCM, webservice dapat menentukan penerima dari notifikasi yang akan dikirim. Firebase Cloud Messaging berfungsi untuk mengirimkan notifikasi ke website yang dituju sesuai dengan token yang dikirim sebelumnya. Firebase Cloud Messaging berfungsi untuk mengirimkan notifikasi ke device Android yang dituju sesuai dengan token yang dikirim sebelumnya. Webservice akan melakukan request ke Google Client untuk verifikasi login menggunakan akun Google. Google Client akan mengembalikan informasi data user sesuai dengan token yang telah dikirimkan pada tahap sebelumnya. Website perpustakaan dapat melakukan request pada webservice untuk memasukkan data pada database. Selain itu melalui webservice website perpustakaan dapat mengubah dan melihat data yang ada pada database. Pada tahap ini website perpustakaan dapat meminta token dari transaksi Midtrans. Webservice akan mengembalikan data dari permintaan website perpustakaan. Webservice akan mendaftarkan transaksi pembayaran pada Midtrans. Midtrans akan mengembalikan token transaksi yang diminta sebelumnya. Sebelum transaksi menggunakan Midtrans dibutuhkan

Malvin Patrick Kurniawan [Website Perpustakaan “Library HUB” Dengan Pencarian Buku Berdasarkan Gambar Menggunakan Google MLKit] 
pendaftaran transaksi untuk mendapatkan token seperti yang telah dijelaskan sebelumnya. Selanjutnya website perpustakaan akan mengirimkan token transaksi ke Midtrans yang didapatkan dari webservice. Midtrans akan memvalidasi token, apabila token sesuai maka midtrans akan membuka snap untuk user melakukan pembayaran. Hal yang sama berlaku untuk transaksi yang terjadi melalui aplikasi Android.

\section{HASIL DAN PEMBAHASAN}

Sebagai hasil dalam penelitian ini, peneliti membuat website dan aplikasi android untuk mendukung sistem perpustakaan penghubung ini atau "LIBRARY HUB". Peneliti akan menampilkan hasil berupa tampilan website dan tampilan aplikasi Android. Website ditujukan untuk digunakan oleh perpustakaan, sedangkan aplikasi Android digunakan oleh mahasiswa Universitas atau Perguruan Tinggi yang terdaftar. Selain itu sebagai bentuk dari uji coba, peneliti melakukan uji coba penerimaan user atau user acceptance test terhadap aplikasi Android yang dibuat.

\subsection{Hasil Tampilan Website}

Desain tampilan ini akan digunakan oleh perpustakaan untuk melakukan administrasi perpustakaan, mulai dari mendata member, sampai dengan peminjaman. Website dibuat dengan menggunakan template AdminLTE versi 2.4.15 yang berbasis bootstrap versi 3 .

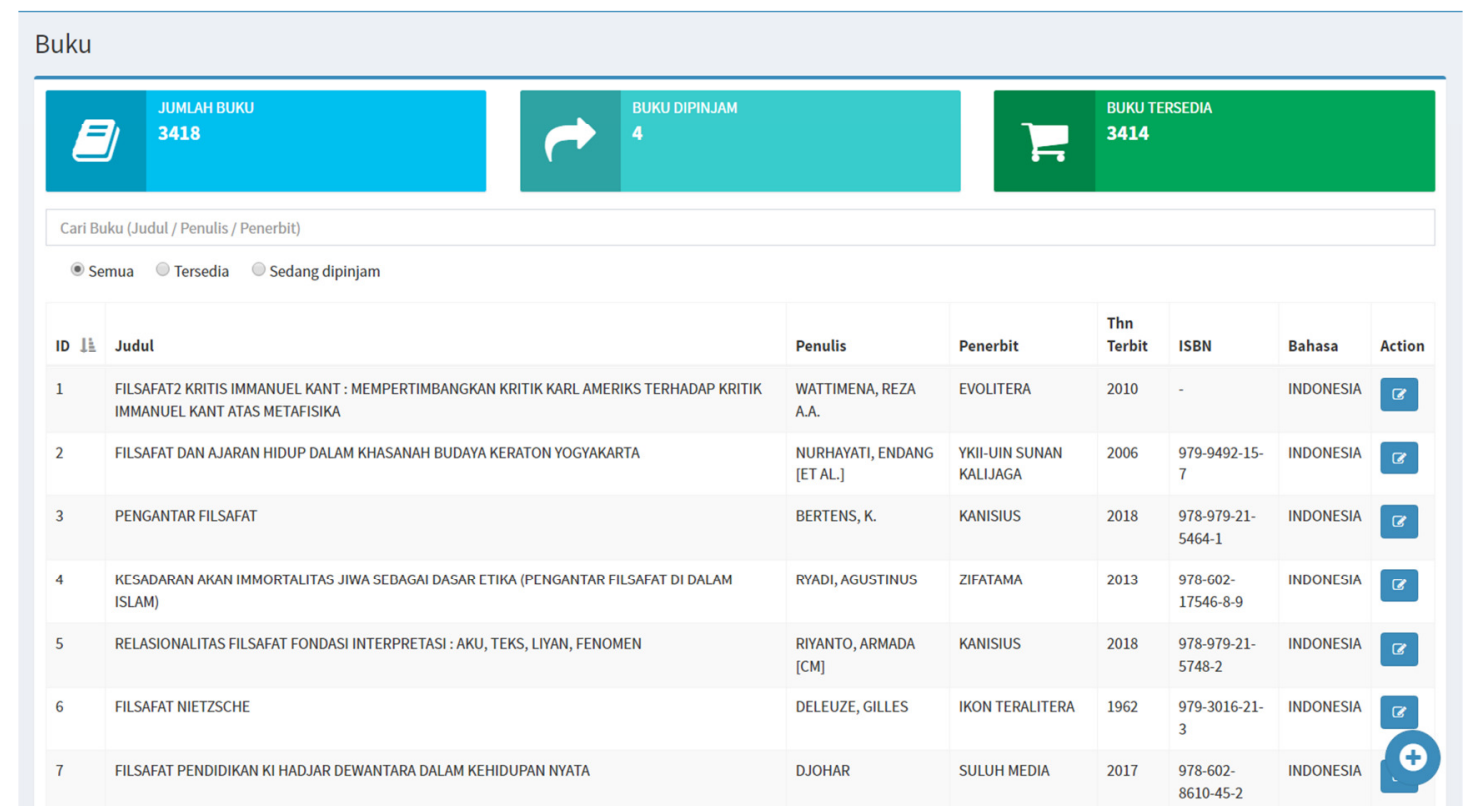

Gambar 4. Fasilitas Master Buku

Pada tampilan fitur master buku terdapat 3 card pada bagian atas yang menunjukkan jumlah buku yang dimiliki, jumlah buku yang sedang dipinjam, dan jumlah buku yang tersisa. Terdapat tabel yang berisikan data-data buku. Selain itu terdapat filter yang berupa isian text untuk melakukan pencarian dan filter status buku. Pada bagian kanan setiap data terdapat tombol untuk melakukan edit data buku. Bagian bawah tampilan terdapat tombol berbentuk lingkaran untuk menambahkan data buku baru. 


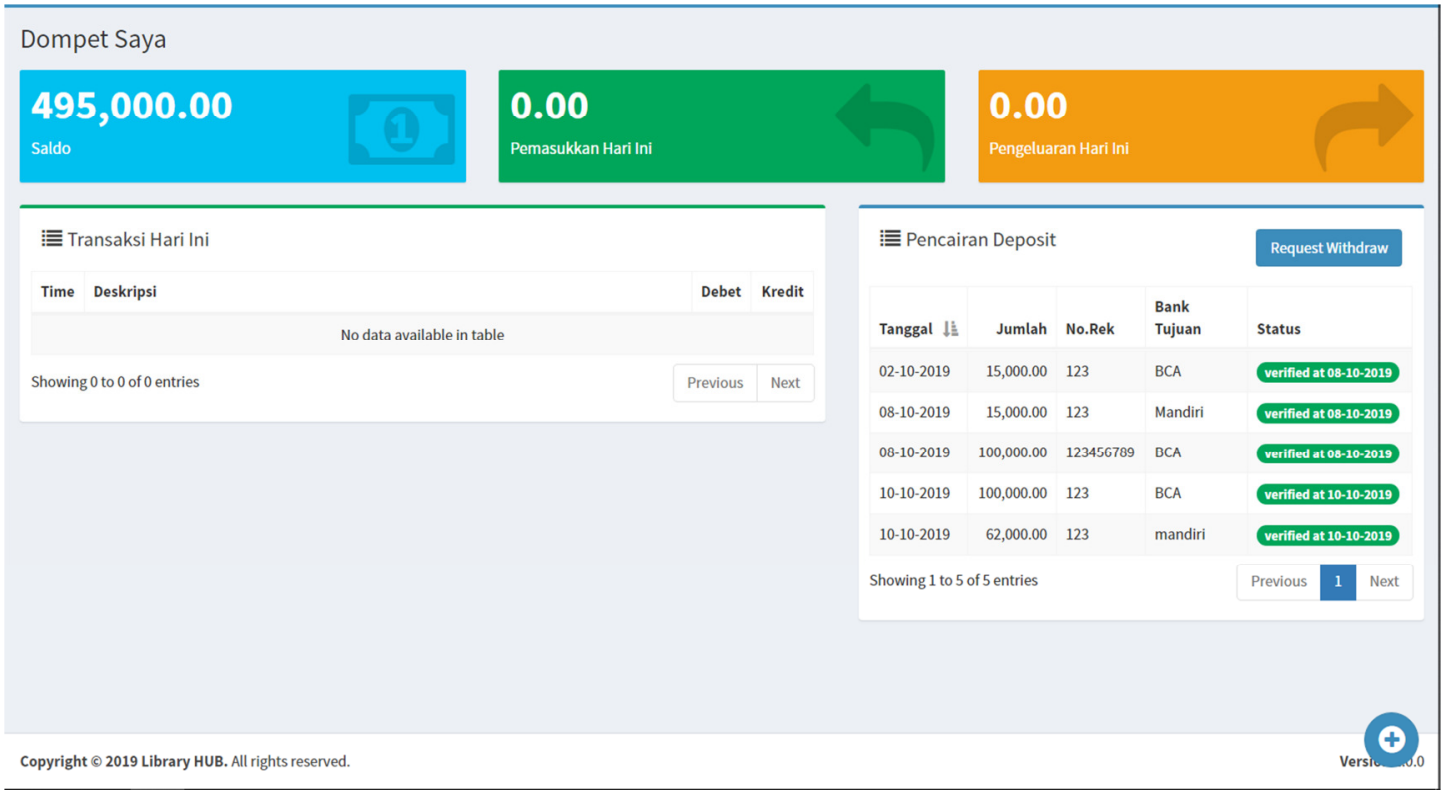

Gambar 5. Fasilitas Fitur Dompet Perpustakaan

Pada bagian atas tampilan terdapat 3 card yang menampilkan jumlah saldo yang dimiliki, transaksi masuk hari ini, dan transaksi keluar hari ini. Transaksi masuk adalah transaksi wallet yang berasal dari biaya peminjaman buku, sedangkan transaksi keluar merupakan transaksi topup wallet member. Pada bagian tengah terdapat 2 tabel yang menampilkan transaksi yang terjadi hari ini dan daftar request pencairan dana. Tabel request withdraw akan disortir berdasarkan tanggal request paling baru. Terdapat tombol "Request Withdraw" yang terdapat pada atas tabel yang digunakan untuk melakukan request pencairan dana kepada admin. Selain itu terdapat tombol lingkaran pada bagian bawah kanan yang digunakan untuk melalukan topup wallet perpustakaan. Topup wallet perpustakaan akan menggunakan Midtrans sebagai payment gateway.

\subsection{Hasil Tampilan Android}

Desain tampilan ini akan digunakan oleh member perpustakaan untuk melakukan peminjaman koleksi pada perpustakaan, mulai dari mencari buku, sampai dengan peminjaman. Tampilan dibuat dengan menggunakan komponen yang tersedia pada Android Studio. 

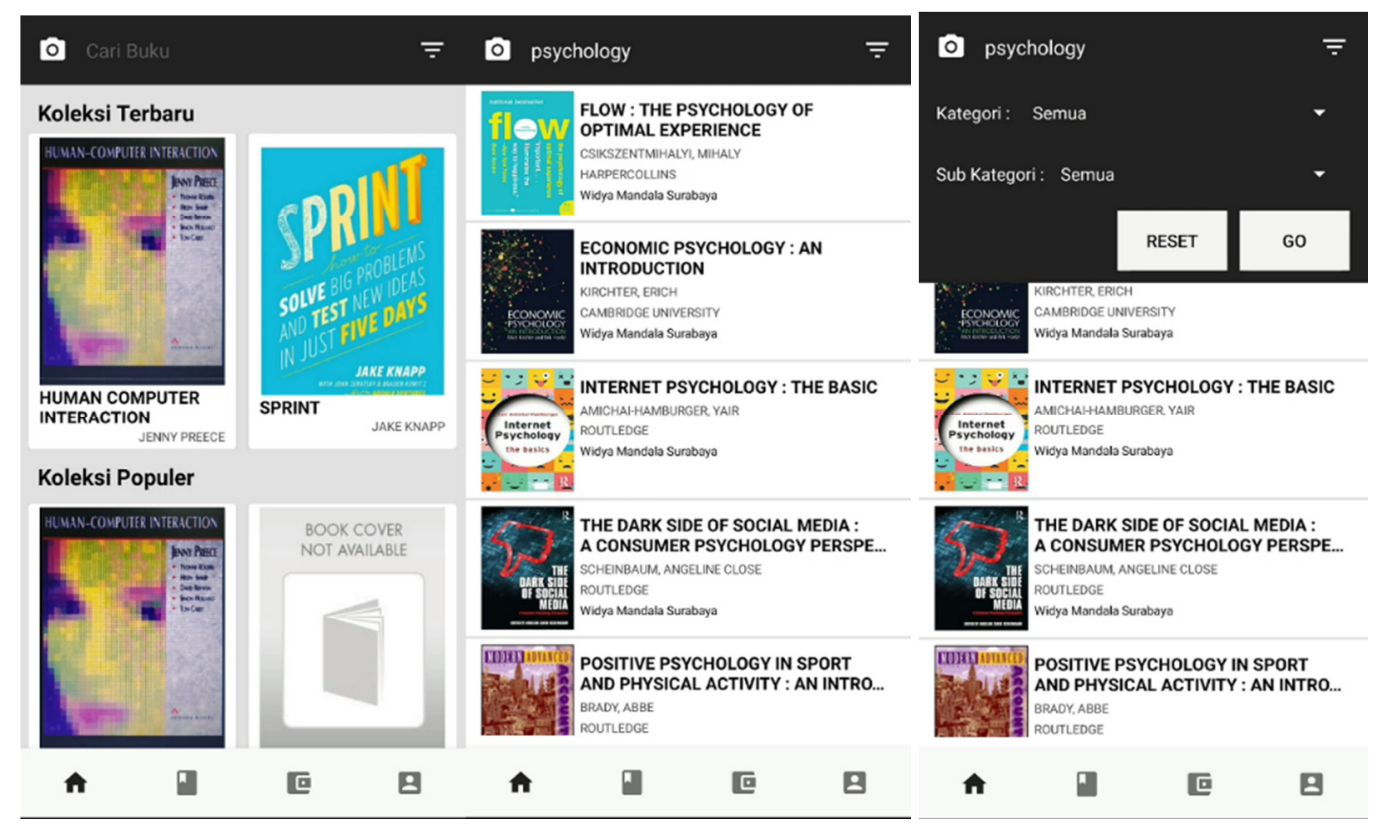

Gambar 6. Activity Utama Aplikasi

Pada halaman utama memiliki beberapa fungsi seperti pencarian buku dan filter hasil pencarian. Gambar 6 bagian kiri merupakan tampilan halaman utama yang menampilkan koleksi buku terbaru dan terpopuler dari semua perpustakaan. Gambar 6 bagian tengah menampilkan hasil pencarian buku berdasarkan judul yang diinputkan. Terdapat tombol berlogo kamera pada kiri isian pencarian digunakan untuk mencari buku berdasarkan gambar. Hasil teks deteksi akan otomatis masuk pada isian pencarian. Pada bagian kanan terdapat tombol untuk melakukan filter pencarian.

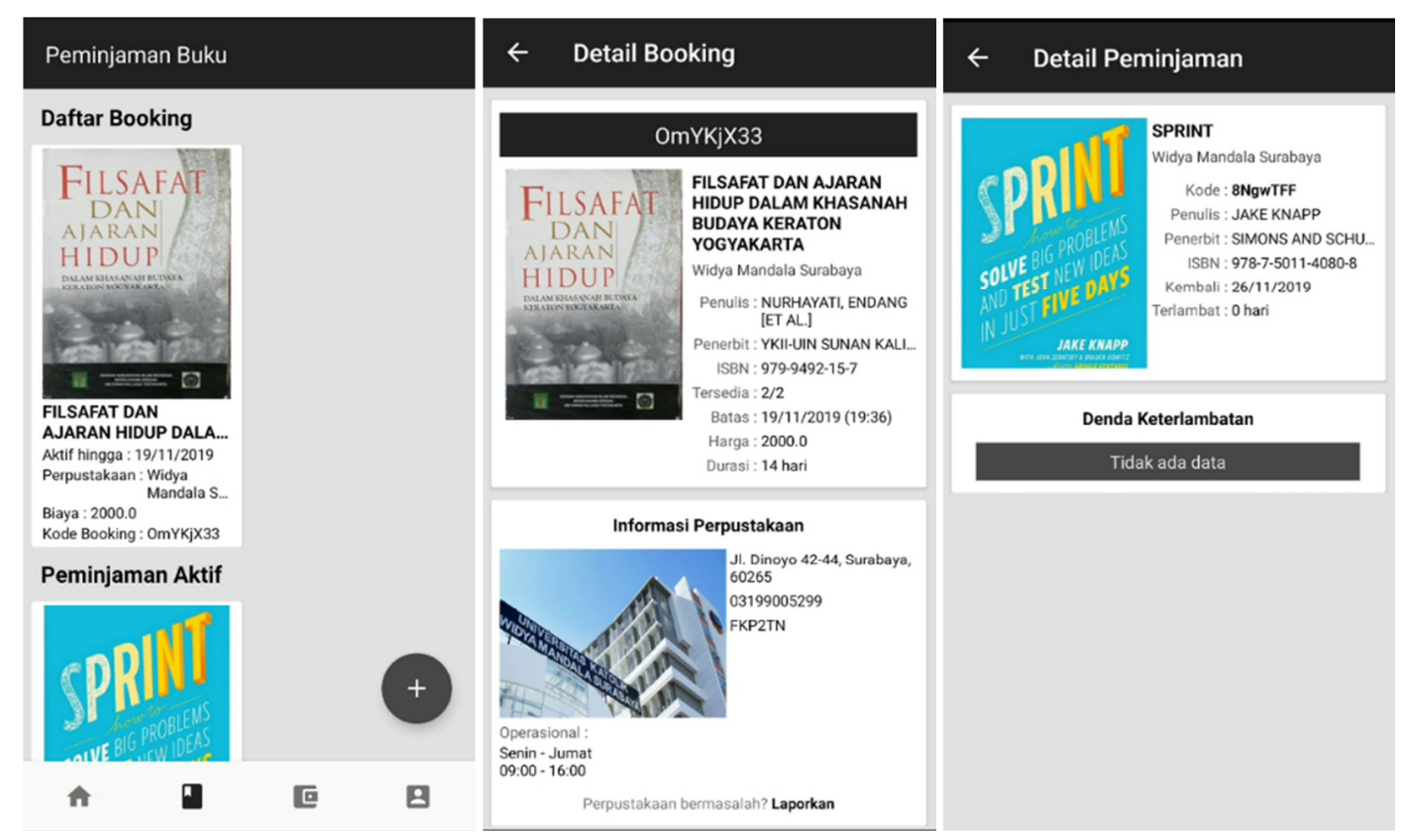

Gambar 7. Activity Peminjaman, Booking, dan Detail Pinjaman

Malvin Patrick Kurniawan [Website Perpustakaan “Library HUB” Dengan Pencarian Buku Berdasarkan Gambar Menggunakan Google MLKit] 
Gambar 7 bagian kiri merupakan tampilan halaman peminjaman buku. Terdapat card yang menampilkan daftar buku yang dibooking dan buku yang sedang dipinjam oleh member. terdapat tombol berbentuk lingkaran pada bagian bawah digunakan untuk melakukan request buku pada suatu perpustakaan. Gambar 7 bagian tengah menampilkan apabila daftar booking ditekan, maka akan menampilkan detail informasi data booking. Selain itu terdapat informasi perpustakaan antara lain: alamat perpustakaan, nomor telepon perpustakaan, keanggotaan perpustakaan, dan keterangan operasional perpustakaan. Gambar 7 bagian kanan akan menampilkan detail informasi ketika card peminjaman aktif ditekan. Apabila peminjaman mengalami keterlambatan, maka akan ditampilkan daftar transaksi denda keterlambatan.

\subsection{User Acceptance Testing}

Uji coba penerimaan pengguna dilakukan dengan menggunakan sampel mahasiswa ISTTS sebanyak 24 orang. Untuk melakukan uji coba, tester akan mendownload file APK terlebih dahulu, kemudian menginstall aplikasi pada device Android masing-masing tester. Respon dari tester akan ditampung dalam kuesioner dengan menggunakan Google Form.

Tabel 1. Hasil Jawaban Kuesioner 1

\begin{tabular}{|l|c|c|c|c|}
\hline \multicolumn{1}{|c|}{ Pertanyaan } & 0 poin & 1 poin & 2 poin & 3 poin \\
\hline Apakah tampilan aplikasi mudah dipahami? & $0 \%$ & $8.3 \%$ & $37.5 \%$ & $54.2 \%$ \\
\hline Apakah tampilkan aplikasi mudah untuk digunakan? & $0 \%$ & $8.3 \%$ & $41.7 \%$ & $50 \%$ \\
\hline $\begin{array}{l}\text { Apakah fitur pencarian buku berdasarkan gambar pada } \\
\text { aplikasi membantu pencarian buku? }\end{array}$ & $6.3 \%$ & $6.3 \%$ & $50 \%$ & $37.5 \%$ \\
\hline
\end{tabular}

Presentasi jawaban bernilai 0 sampai 3, dimana semakin kecil nilai jawaban, semakin buruk penilaian kuesioner. Dari hasil kuesioner yang diajukan pada tester, maka dapat disimpulkan bahwa secara tampilan, aplikasi mudah untuk dipahami dan digunakan. Berdasarkan jawaban kuesioner, hanya didapatkan $8.3 \%$ responden yang memberikan respons buruk pada aplikasi. Selain itu fitur pencarian berdasarkan gambar membantu pencarian buku dengan respon nilai $50 \%$ respon membantu dan $37.5 \%$ respon sangat membantu.

Gambar 8 merupakan grafik hasil kuesioner penilaian terhadap 3 pertanyaan yaitu "Apakah tampilan aplikasi nyaman untuk dilihat? (dari segi warna, jenis komponen, ukuran komponen, dan tata letak komponen)", "Apakah informasi dalam aplikasi mudah dicari atau ditemukan?", dan "Apakah respons yang diberikan aplikasi sesuai dengan yang diharapkan?". Data disajikan dalam bentuk bar chart sehingga mudah dipahami. 


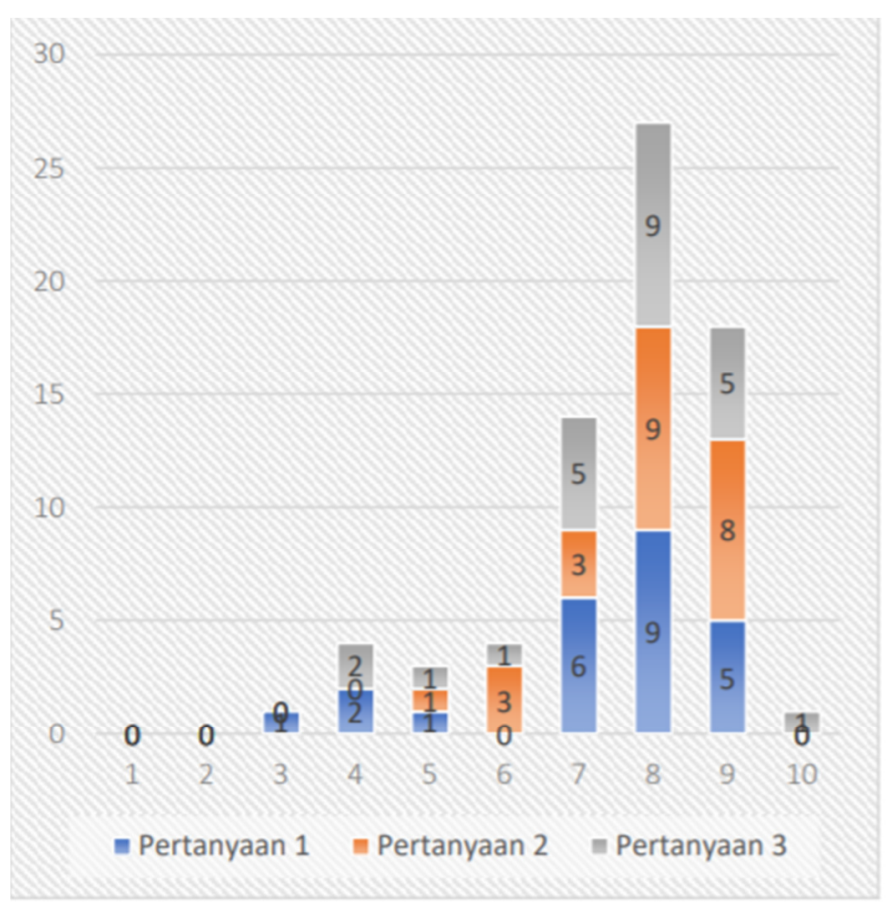

Gambar 8. Hasil Penilaian Kuesioner 2

Dari hasil penilaian terhadap tampilan dapat disimpulkan bahwa aplikasi nyaman untuk dilihat dengan perolehan nilai total $82.5 \%$ pada range 7-10 poin. Pada pertanyaan kedua, dapat disimpulkan bahwa informasi pada aplikasi mudah dicari atau ditemukan. Dapat dilihat bahwa diperoleh $83.3 \%$ pada range 7-10 poin. Pada pertanyaan ketiga, dapat disimpulkan bahwa aplikasi telah merespons dengan baik sesuai harapan pengguna. Pada gambar 8 dapat dilihat bahwa $83.3 \%$ pengguna merespons dengan memberikan jawaban antara 7-10 poin.

\section{KESIMPULAN}

Dari penelitian yang telah dilakukan dapat ditarik beberapa kesimpulan. Hasil deteksi teks menggunakan Google MLKit Text Recognition hanya bersifat membantu, tidak dapat menggantikan pencarian manual secara keseluruhan. Selain itu, perubahan library yang terus berkembang akan mempengaruhi alur implementasi. Pada penelitian ini digunakan beberapa pihak ketiga seperti Firebase, Google Client, MLKit, dan Midtrans yang akan terus dikembangkan. Dalam hal pembuatan aplikasi Android native menggunakan bahasa Kotlin mempercepat performance dari aplikasi, karena tipe variabel yang digunakan sama. Selain itu terdapat anotasi NullPointerException sehingga aplikasi tidak akan force close ketika diberikan nilai null. Penelitian ini telah melakukan user acceptance testing, dan berdasarkan penilaian kuesioner yang dijawab oleh responden, pencarian buku berdasarkan gambar membantu pencarian buku sebesar $87.5 \%$. 


\section{SARAN}

Terdapat beberapa saran untuk untuk penelitian lebih lanjut untuk menutup kekurangan penelitian, seperti penambahan implementasi Natural Language Processing untuk mendeteksi lebih dalam kalimat dalam judul buku. Selain itu, karena adanya perubahan library yang terus berkembang, maka perlu dilakukan maintenance aplikasi secara berkala. Konsep pemrograman berorientasi objek murni dapat mempercepat dan mempermudah proses pengerjaan aplikasi Android dan website.

\section{DAFTAR PUSTAKA}

[1] FPPTI Jawa Timur, “Tentang Kartu SUPER," Website. https://fpptijatim.or.id/public/kartu-super/tentang-kartu-super/.

[2] A. Veronica, 2019, "Resource Sharing: Perspektif Perpustakaan Universitas Esa Unggul,” Khizanah al-Hikmah J. Ilmu Perpustakaan, Informasi, dan Kearsipan, Vol. 7, No. 1, p. 75, doi: 10.24252/kah.v7ila7.

[3] 2015, Perpustakaan Nasional Republik Indonesia, Pedoman Penyelenggaraan Perpustakaan Perguruan Tinggi Perpustakaan Nasional Republik Indonesia.

[4] Salmubi, "Pelestarian Khasanah Budaya Bangsa Lewat Kerjasama Perpustakaan dan Resource Sharing: Sebuah Peran Perpustakaan Nasional,” Visi Pustaka, Dec. 2006.

[5] S. Rahman, 2018, "Apa itu Framework?," Website, https://www.devaradise.com/id/2013/12/mengenal-pengertian-framework-website.html (accessed Mar. 19, 2021).

[6] R. Fajar, "Yuk Belajar Angular.js Bareng Learn Angular," Website, 2015. https://www.codepolitan.com/yuk-belajar-angular-js-bareng-learn-angular (accessed Mar. 21, 2021).

[7] A. Nugroho, 2021, "Mengenal Apa Itu Firebase dan Kegunaannya," Website, https://qwords.com/blog/firebase-adalah/, (accessed Jul. 31, 2021).

[8] D. Tidwell, J. Snell, and P. Kulchenko, 2001, Programming Web Services with SOAP, First Ed. O’Reilly Media, Inc.,

[9] G. Developers, "MLKit Recognize Text," Website. https://developers.google.com/mlkit/vision/text-recognition (accessed May 09, 2021).

[10] M. Mohammed, M. B. Khan, and E. B. M. Bashier, 2016, Machine Learning: Algorithms and Applications. CRC Press,. 